\title{
Glitazar Antidiabetic Agent
}

National Cancer Institute

\section{Source}

National Cancer Institute. Glitazar Antidiabetic Agent. NCI Thesaurus. Code C98233.

Any agent within the glitazar class that are dual or pan-acting peroxisome proliferatoractivated receptor (PPAR) agonists with insulin sensitizing and lipid lowering activity. Glitarzars bind to two or more subtypes of PPAR isoforms, and result in improving hyperg lycemia and lipid abnormalities as seen by decreasing levels of glucose, triglycerides and increasing levels of HDL cholesterol. These agents may be used to improve glucose tolerance without inducing adiposity and body weight gain. PPARs function as transcription factors that regulate expressions of genes involved in cellular differentiation, development, and metabolism (carbohydrate, lipid, protein), and tumorigenesis. 